\title{
Analisis Wacana Kritis Pendidikan Multikultural dan Pendidikan Nilai Dalam Buku Teks Sejarah SMA
}

\section{Critical Discourse Analysis of Multicultural Education and Value Education in Senior High School Historical Textbooks}

\author{
Danan Tricahyono $^{\text {a, }}{ }^{*}$, Sariyatun ${ }^{\text {b, } 2 \text {, Suryo Ediyono }}{ }^{\text {c, } 3}$ \\ a,b,c Magister Pendidikan Sejarah, Universitas Sebelas Maret, Indonesia \\ 11 danancahyono2@gmail.com; ${ }^{2}$ sarifkipuns@yahoo.co.id; ${ }^{3}$ ediyonosuryo@yahoo.com
}

\begin{tabular}{ll}
\hline Informasi artikel \\
\hline Sejarah artikel: & \\
Diterima & $: 9$ Juni 2020 \\
Revisi & $: 5$ Agustus 2020 \\
Dipublikasikan $\quad: 14$ Agustus 2020 \\
\hline Kata kunci: \\
Wacana \\
Multikulturalisme \\
Pendidikan Nilai \\
Buku Teks Sejarah
\end{tabular}

\section{ABSTRAK}

Tujuan penelitian ini untuk mengetahui wacana pendidikan multikultural dan pendidikan nilai dalam buku teks pelajaran sejarah SMA. Penelitian ini menggunakan metode studi analisis wacana kritis dari Norman Fairclough yang terdiri dari tiga tahap. Pertama analisis teks, kedua analisis praktik diskursif, Ketiga praksis sosial. Analisis penelitian dilakukan dengan menggunakan cara deskripsi, interpretasi dan eksplanasi. Peneliti melakukan analisis terhadap buku teks Sejarah Indonesia kelas X revisi tahun 2017. Hasil penelitian menunjukan ditemukan sebelas narasi teks yang merepresentasikan pendidikan multikultural dan pendidikan nilai. Pada bab I Menelusuri Peradaban Awal Di Kepulauan Indonesia terdapat satu wacana toleransi terhadap keberagaman suku bangsa di Indonesia. Pada bab II Pedagang, Penguasa Dan Pujangga Masa Klasik (Hindu Dan Budha) terdapat wacana toleransi terhadap keberagaman etnis dan agama. Pada bab III Islamisasi dan Silang Budaya di Nusantara terdapat wacana gotong royong, akulturasi dan humanisme. Simpulan penelitian peranan guru menjadi penting untuk menghadirkan pembelajaran yang berorientasi pada pembentukan karakter. Melalui proses pembiasaan dan keteladanan yang diambil dari muatan buku teks tentang nilai multikulturalisme dan pendidikan nilai guna dijadikan pedoman bagi siswa untuk berperilaku dalam kehidupan seharihari.

\author{
Keywords: \\ Discourse \\ Multiculturalism \\ Value education \\ Historical textbooks
}

\section{ABSTRACT}

The purpose of this study was to determine the multicultural education and value education discourse in high school history textbooks. This research uses the study method of critical discourse analysis from Norman Fairclough which consists of three steps. First text analysis, a second analysis of discursive practices, Thirdsocial praxis. Analysis of the research was carried out using description, interpretation, and explanation. Researchers analyzed textbooks on the history of Indonesian X grade revised in 2017. The results showed that eleven text narratives were representing multicultural education and value education. In Chapter I Tracing Early Civilizations in the Indonesian Archipelago there is a discourse of tolerance towards ethnic diversity in Indonesia. In Chapter II Traders, Rulers, and Poets of the Classical Period (Hinduism and Buddhism) there is a discourse of tolerance towards ethnic and religious diversity. In chapter III Islamization and Cultural Crossage in the Archipelago, there is the discourse of cooperation, acculturation, and humanism. The conclusion of the teacher's role is important in presenting learning that is oriented 
towards character building. Through the process of habituation and example taken from the contents of textbooks about the value of multiculturalism and value education to be used as a guide for students to behave in everyday life.

\section{Pendahuluan}

Pembelajaran sejarah merupakan proses kegiatan siswa bersama guru dengan mendayagunakan fasilitas pembelajaran serta materi sejarah yang di dalamnya mengandung nilai-nilai kearifan yang memiliki manfaat untuk mengembangkan kecerdasan, sikap dan pembentukan karakter siswa. Jadi, dari pembelajaran sejarah siswa diarahkan untuk memiliki kepribadian yang baik dengan mengambil nilai-nilai positif dari peristiwa di masa lalu untuk dijadikan pedoman dalam kehidupan sehari-hari. Beberapa tujuan pembelajaran sejarah diantaranya: Pertama, mengembangkan pemahaman tentang diri sendiri. Kedua, mengajarkan prinsip moral. Ketiga, mengajarkan toleransi. Keempat, memperkokoh rasa nasionalisme (Kochar, 2008). Apabila tujuan pembelajaran sejarah dapat tercapai semua maka siswa dimungkinkan dapat memaknai nilai-nilai kehidupan masa lalu untuk dijadikan pedoman menjalani kehidupan di masa kini.

Penerapan pembelajaran sejarah pada praktiknya belum semuanya sesuai dengan prinsip penyelenggaraan pendidikan nasional seperti: Pertama, pendidikan harus diselenggarakan secara demokratis dan berkeadilan serta tidak diskriminatif dengan menjujung tinggi hak asasi manusia, nilai keagamaan, budaya dan kemajemukan. Kedua, pendidikan diselenggarakan dengan memberi keteladanan, membangun kemauan dan mengembangkan kreativitas siswa dalam proses pembelajaran (Undang-Undang Nomor 20 Tentang Sistem Pendidikan Nasional, 2003). Dampaknya para siswa mungkin hanya mengalami perubahan dari sisi aspek kognitifnya sementara dari sisi kepribadian (karakter) masih tetap. Contoh kasus saat ujian di kelas terdapat beberapa siswa yang bersikap tidak jujur, para pelajar masih banyak bersikap intoleran terhadap sesama teman. Sikap intoleran apabila dibiarkan akan memberikan ancaman terhadap keutuhan bangsa Indonesia. Contohcontoh tersebut menjadi bukti jika pembelajaran sejarah ikut bertanggungjawab untuk berkontribusi membentuk karakter siswa. Hal ini tidak lepas dari keberadaan mata pelajaran sejarah yang memiliki orientasi pengambilan nilai positif dari narasi peristiwa masa lalu.

Beberapa alternatif guna menghasilkan pembelajaran sejarah yang berorientasi nilai dapat dilakukan dengan mengimplementasikan pendidikan multikulturalisme dan pendidikan nilai sebagai landasan pembelajaran. Pendidikan multikulturalisme secara sederhana berarti pengembangan pengetahuan dan penghargaan terhadap keanekaragaman budaya (Lickona, 2019). Bank dalam (Ozturgut, 2011) menjelaskan bahwa konsep pendidikan multikultural adalah adanya keseteraan diantara siswa laki-laki dan perempuan tanpa memandang ras, etnis, bahasa dan budaya dalam mendapatkan kesempatan bersama di sekolah. Sementara pendidikan nilai dapat dimaknai sebagai proses pendidikan yang berorientasi pada penanaman nilai-nilai kehidupan seperti nilai agama, budaya, etika dan estetika menuju pembentukan pribadi siswa yang memiliki kecerdasan spiritual keagamaan, pengendalian diri, kepribadian 
yang utuh, berakhlak mulia, serta keterampilan yang diperlukan dirinya, masyarakat dan negara (Zakiyah \& Rudiana, 2014). Buku teks sejarah merupakan salah satu perangkat pembelajaran yang efektif dan efisien guna menunjang pembelajaran (Yuberti, 2014).

Uraian materi yang tersaji dalam buku teks merupakan pengembangan Kompetensi Inti (KI) dan Kompetensi Dasar (KD) yang terdapat dalam kurikulum. Penulisan materi buku teks oleh penulis dilakukan dengan cara menginterpretasikan terhadap Keterkaitan KI dan KD yang disesuaikan dengan tujuan pembelajaran. Dalam K-13 arah pembelajarannya menempatkan aspek sikap sebagai tujuan utama baru diikuti aspek pengetahuan dan keterampilan. Dengan demikian materi buku teks sebagai bahan ajar standart yang diterbitkan oleh negara sangat dipengaruhi oleh kepentingan pemerintah. Dalam hal ini pemerintah melalui implementasi K-13 mewacanakan pendidikan karakter melalui pembelajaran. Wujud pendidikan karakter adalah integrasi nilai pendidikan multikultural dan pendidikan nilai dalam pembelajaran. Pembentukan sikap atau karakter terhadap siswa diberikan melalui pengajaran tidak langsung. Oleh karena itu, pada artikel ini peneliti mencoba menganalisis wacana tentang pendidikan multikultural dan pendidikan nilai yang termuat dalam buku teks sejarah SMA. Sehingga muatan-muatan tersebut dapat dijadikan sebagai materi untuk pembentukan karakter siswa.

\section{Metode}

Penelitian ini menggunakan metode studi analisis wacana kritis dari Norman Fairclough yang terdiri dari tiga tahap. Pertama analisis teks, hal ini berkenaan dengan analisa pada genre, wacana dan penggunaan perbendaharaan kata yang memiliki makna tertentu, penggunaan istilah dan metafora yang mengacu ke makna atau tindakan terentu. Setiap kata memiliki banyak makna bergantung dengan konteksnya maka peneliti dituntut jeli memahaminya (Fairclough, 2015). Kedua analisis praktik diskursif, hal ini melihat kekuatan pernyatan dalam arti sejauh mana mendorong tindakan atau kekuatan afirmatifnya, dalam dimensi ini akan dilihat koherensi teks-teks yang sudah masuk ke wilayah interpretasi. Pada tahap ini intertektualitas teks sudah mendapat perhatian khusus (Haryatmoko, 2019). Ketiga praksis sosial, tahap ini akan menggambarkan aktivitas sosial, bagaimana hubungan aktivitas sosial dengan tatanan sosial masyarakat, institusi dan organisasi. Unsurunsur tersebut selalu menggunakan bahasa khusus, hal ini tidak lepas jika sebuah wacana selalu berkelindan dengan berbagai tingkatannya, dalam situasi langsung, dalam intitusi atau organisasi yang lebih luas pada tingkat masyarakat (Fairclough, 2015). Jadi analisis penelitiannya secara sederhana meliputi deskripsi, interpretasi dan eksplanasi (Haryatmoko, 2019). Peneliti melakukan analisis terhadap buku teks Sejarah Indonesia kelas X edisi revisi tahun 2017. Buku tersebut ditulis oleh Restu Gunawan, Amurwani Dwi Lestariningsih, dan Sardiman yang diterbitkan oleh Kementerian Pendidikan dan Kebudayaan (Gunawan et al., 2017).

\section{Hasil dan Pembahasan}

Buku teks Sejarah Indonesia kelas X memiliki 3 bab yang terdiri dari: Bab I Menelusuri Peradaban Awal di Kepulauan Indonesia. Bab II Pedagang, Penguasa dan Pujangga Masa Klasik (Hindu dan Budha). Bab III Islamisasi dan Silang Budaya di Nusantara.

Analisis teks 1 pada bab I Menelusuri Peradaban Awal di Kepulauan Indonesia, Sub bab Asal-Usul dan Persebaran Nenek Moyang 
Bangsa Indonesia halaman. Pada hal 34 terdapat deskripsi.

.... banyaknya suku
bangsa di Indonesia jelas
memunculkan keberagaman
bahasadaerahdankebudayaan
... lebih dari 500 suku bangsa
Indonesia. Sungguh merupakan
kekayaan bangsa yang tidak
dimiliki oleh negara lain.
Namun demikian kekayaan ini
menjadi masalah jika tidak
pandai mengelola perbedaan
yang ada. Tentu ini berkaitan
pula dengan asal mula
kedatangan suku bangsa dan
waktu kedatangan mereka. ....
penting untuk mengetahui
bagaimana proses dan
dinamika nenek moyang
Indonesia sehingga terbentuk
keragaman budayanya.

Kalimat tersebut memberikan gambaran apabila penulis buku ingin menyampaikan sebuah pengantar materi tentang asal-usul nenek moyang Bangsa Indonesia yang berasal dari beberapa kawasan di belahan bumi. Ras-ras dari berbagai kawasan tersebut datang secara periodik dengan membawa ciri masing-masing baik dari segi fisik dan kebudayaan. Pertama, ras Proto Melayu sebagai ras tertua berasal dari daerah Yunnan yang memiliki ciri kulit kuning, mata sipit, dan rambut lurus mereka bermigrasi ke daerah Indocina terus masuk ke Pulau Sumatra, Kalimantan, dan Sulawesi. Kedua, ras Deutro Melayu yang berasal dari sebelah utara Indocina dengan membawa kebudayaan Dongson yang mendiami Jawa, Sumatra dan Kalimantan. Ketiga, ras Melanesoid mendiami wilayah Papua Barat, Ambon, Maluku Utara dan Nusa Tenggara Timur. Keempat, ras Negrito dan Weddid yang masih terus diteliti asal-usulnya, mereka mendiami beberapa daerah seperti di Palembang dan Jambi, di Siak (Sakai) dan di Sulawesi Tenggara (Toala, Tokea dan Tomuna).

Uraian materi yang ditulis miring merepresentasikan wacana pindidikan multikultural berupa toleransi terhadap keanekaragaman suku bangsa. Dengan mempelajari sejarah asal-usul nenek moyang yang berasal dari berbagai kawasan sehingga terjadi akulturasi dan asimilasi dalam perjalanannya. Sebagai akibatnya muncul berbagai macam suku bangsa di Indonesia dengan ciri-ciri fisik dan kebudayaan yang beragam. Diharapkan para pembaca dapat tumbuh sikap menghargai dan menghormati. Rasa hormat direfleksikan dalam wujud toleransi terhadap setiap perbedaan yang dilihatnya. Perbedaan tersebut berupa ciri-ciri fisik maupun kebudayaannya yang termanifestasikan dalam cara hidup suku-suku yang mendiami beberapa kawasan di Nusantara.

Analisis teks 2 pada bab II Pedagang, Penguasa dan Pujangga Masa Klasik (Hindu dan Budha), Sub bab Pengaruh Budaya India. Pada halaman 76 terdapat deskripsi.

.... di Sumatra terdapat kerajaan yang sangat terkenal yaitu Sriwijaya. Kerajaan yang handal menjalin hubungan dengan dunia internasional melalui jaringan perdagangan dan kemaritimannya. Dalam masa itulah para pedagang datang dari India, Cina, dan Arab untuk meramaikan Sriwijaya. ... Pada masa itu pula hubungan dengan India dan Cina berkembang pesat. Bahkan hubungan itu sangat 
berpengaruh dalam

perkembangan budaya masa

itu, bahkan hingga saat ini

pengaruh kedua budaya itu

masih dapat kita temui.

Narasi kalimatnya menguraikan karakteristik keberadaan Sriwijaya sebagai kerajaan maritim yang sangat terbuka dengan para pedagang dari luar negeri seperti Arab, Cina dan India. Keterbukaan tersebut mengakibatkan terjadinya kontak kebudayaan dengan penduduk lokal. Para pedagang dari masing-masing negara membawa kebudayaan masing-masing. Pedagang Arab membawa kebudayaan Islam sementara pedagang dari India membawa kebudayaan Hindu atau Budha. Proses akulturasi budaya tersebut nyatanya bisa diterima oleh masyarakat Sriwijaya saat itu dan masih bisa bertahan sampai sekarang.

Wacana yang direpresentasikan berupa pendidikan multikultural tentang toleransi terhadap etnis dan pentingnya nilai kerukunan. Teks tersebut merepresentasikan penghargaan terhadap keanekaragaman kebudayaan. Sehingga muncul kehidupan multi etnis yang harmonis di masyarakat.

Analisis teks 3 pada bab II Pedagang, Penguasa dan Pujangga Masa Klasik (Hindu dan Budha), Sub bab Kerajaan-Kerajaan pada Masa Hindu-Budha. Pada halaman 94-95 terdapat deskripsi.

\section{Dalam kehidupan} agama, sebagian besar masyarakat Tarumanegara memeluk agama Hindu. Sedikit yang beragama Buddha dan masih ada yang mempertahankan agama nenek moyang (animisme). Berdasarkan berita dari FaHien, di To-lo-mo
(Tarumanegara) terdapat tiga agama, yakni agama Hindu, agama Buddha dan kepercayaan animisme. Raja memeluk agama Hindu. .... Rakyat Tarumanegara hidup aman dan tenteram.

Kutipan kalimat tersebut menunjukan jika kondisi kehidupan sosial masyarakat Tarumanegara yang terdiri dari tiga kepercayaan dapat hidup damai dan tentram. Teks tersebut di dalamnya terdapat wacana pendidikan multikultural berupa nilai toleransi, kerukunan, demokratis, adil, dan bijaksana. Teks yang merepresentasikan kondisi kehidupan yang adil dan bijaksana terlihat dari uraian agama yang dipeluk raja adalah Hindu sementara untuk beberapa masyarakat memeluk Budha dan anismisme. Raja memiliki toleransi yang tinggi dengan membebaskan rakyatnya untuk memilih kepercayaan masing-masing tanpa adanya paksaan untuk menjadi penganut Hindu. Hal tersebut dibuktikan dengan kalimat "rakyat hidup aman dan tentram". Dari sini diketahui jika toleransi sudah dijunjung tinggi oleh masyarakat Tarumanegara sehingga tercipta kehidupan yang rukun dan demokratis khususnya pada bidang kepercayaan.

Analisis teks 4 pada bab II Pedagang, Penguasa dan Pujangga Masa Klasik (Hindu dan Budha), Sub bab Kerajaan-Kerajaan pada Masa Hindu-Budha. Pada halaman 114 terdapat deskripsi.

\section{.... Setelah kekuasaan}

Penangkaran berakhir, timbul persoalan dalam keluarga Syailendra, karena adanya perpecahan antara anggota keluarga yang sudah memeluk agama Buddha dengan keluarga yang masih memeluk 
agama Hindu (Syiwa). .... Perpecahan di dalam keluarga Syailendra tidak berlangsung lama. Keluarga itu akhirnya bersatu kembali. Hal ini ditandai dengan perkawinan Rakai Pikatan dan keluarga yang beragama Hindu dengan Pramudawardani, putri dari Samaratungga (Budha).

Uraian kalimat tersebut menggambarkan Kerajaan Mataram Kuno Jawa Tengah pada sisi sosialnya berkembang dua agama yang berbeda. Agama Hindu diwakili oleh Dinasti Sanjaya dan agama Budha diwakili oleh Dinasti Syailendra. Perbedaan tersebut pernah menjadikan sebuah perpecahan. Perpecahan tersebut dapat diatasi dengan melakukan perkawinan diantara dua dinasti. Wacana tentang pendidikan mulkulturalnya berupa toleransi dan pengendalian diri. Jika dianalisis konteks kehidupan politik dan sosial di Kerajaan Mataram Kuno, pernikahan antara Rakai Pikatan dengan Pramodyawardani sebagai usaha mendamaikan konflik Dinasti Sanjaya dan Syailendra. Setelah perkawinan tersebut kondisi masyarakat Mataram Kuno Jawa Tengah berangsur-angsur hidup membaik. Diantara masyarakat yang beragama Hindu dan Budha hidup secara berdampingan. Dari sisi agamanya juga berkembang dengan pesat.

Analisis teks 5 pada bab II Pedagang, Penguasa dan Pujangga Masa Klasik (Hindu dan Budha), Sub bab Kerajaan-Kerajaan pada Masa Hindu-Budha. Pada halaman 134 terdapat deskripsi.

... Pada masa
pemerintahan Kertanegara,
agama Hindu maupun Buddha
berkembang dengan baik.
Bahkan terjadi Sinkretisme

antara agama Hindu dan

Buddha, menjadi bentuk Syiwa-

Buddha. Sebagai contoh, berkembangnya aliran

Tantrayana. Kertanegara

sendiri penganut aliran

Tantrayana.

Teks itu menarasikan jika kehidupan beragama masyarakat Singhasari terdapat dua agama yang berkembang yaitu Hindu dan Budha. Keberadaan dua agama justru menjadikan kehidupan masyarakatnya harmonis. Keharmonisan ajaran Hindu dan Budha sampai terjadi sinkritisme. Wacana pendidikan multikulturalnya adalah sikap toleransi antar umat beragama dan ketaatan terhadap suatu ajaran agama. Teks tersebut merepresentasikan kondisi sosial masyarakat Singhasari hidup secara harmonis dengan perbedaan agama bahkan Raja Kertanegara dikenal sebagai penganut aliran Tantrayana yang merupakan sinkritisme dari ajaran Hindu dan Budha.

Analisis teks 6 pada bab II Pedagang, Penguasa dan Pujangga Masa Klasik (Hindu dan Budha), Sub bab Kerajaan-Kerajaan pada Masa Hindu-Budha. Pada halaman 140 terdapat deskripsi.

$\begin{array}{lr}\text {.... } & \text { Kehidupan } \\ \text { beragama di } & \text { Majapahit } \\ \text { berkembang semarak. Pemeluk } \\ \text { yang beragama Hindu maupun } \\ \text { Buddha saling bersatu. Pada } \\ \text { masa itu pun sudah dikenal } \\ \text { semboyan Bhinneka Tunggal } \\ \text { Ika, artinya, sekalipun } \\ \text { berbeda-beda baik Hindu } \\ \text { maupun Buddha pada } \\ \text { hakikatnya adalah satu jua. } \\ \text { Kemudian secara umum kita } \\ \text { artikan berbeda-beda akhirnya } \\ \text { satujua. }\end{array}$


Narasi kalimat itu menunjukan jika kehidupan sosial masyarakat di masa Kerajaan Majapahit hidup secara damai diantara dua agama yaitu Hindu-Budha. Hal tersebut dibuktikan adanya semboyan Bhineka Tunggal Ika yang diambil dari Kitab Sutasoma karangan Mpu Tantular. Wacana pendidikan multukultural yang direpresentasikan oleh narasi tersebut adalah toleransi dan kerukunan. Penulis buku ingin memberikan penekanan jika tunas multikulturalisme yang ada di Indonesia saat ini dimulai dari zaman Majapahit dengan adanya penebalan kata-kata pada semboyan Bhineka Tunggal Ika beserta artinya. Penulis buku ingin mengajak pembaca untuk meneguhkan keyakinan jika sejak zaman Majapahit telah ada sikap menghargai perbedaan. Dengan demikian sudah semestinya cara hidup toleran tersebut diwariskan kepada generasi muda lewat pendidikan khususnya pembelajaran sejarah di sekolah-sekolah.

Analisis teks 7 Bab III Islamisasi dan Silang Budaya di Nusantara, sub bab Islam dan Jaringan Perdagangan Antar Pulau. Pada halaman 181 terdapat deskripsi.

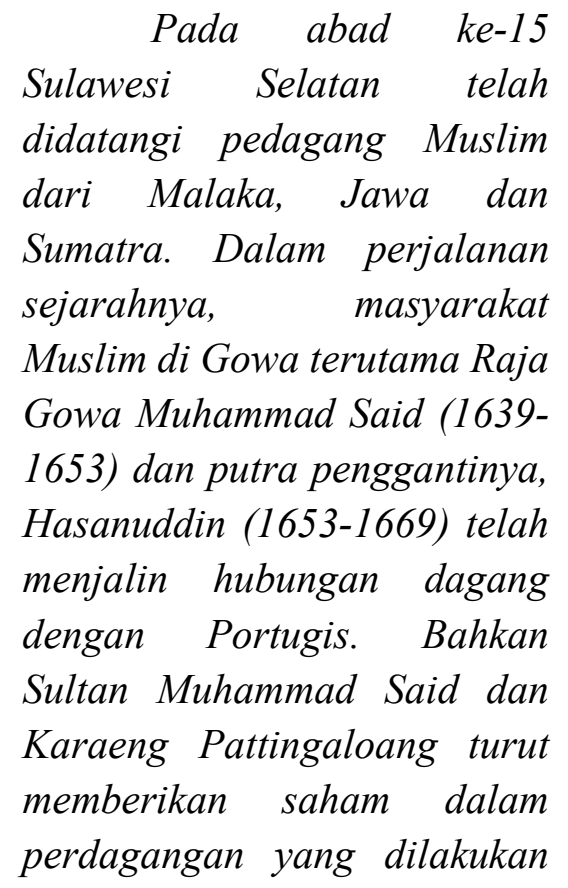

Fr. Vieira, meskipun mereka beragama Katolik. Kerja sama ini didorong oleh adanya usaha monopoli perdagangan rempah-rempah yang dilancarkan oleh kompeni Belanda di Maluku.

Teks tersebut menunjukan apabila jalinan perdagangan muslim telah mulai memasuki kawasan Sulawesi Selatan pada abad 15. Masyarakat muslim di Gowa dalam membangun jaringan perdagangan tidak hanya dengan pedagang muslim. Mereka juga berhubungan dengan Portugis sebagai upaya menandingi tindakan monopoli rempahrempah yang dilakukan oleh pedagang Belanda di Maluku. Wacana pendidikan multikultural dalam narasi tersebut adalah gotong royong dan toleransi. Hal ini terlihat pada kalimat "memberikan saham dalam perdagangan ... meskipun beragama Katolik". Kalimat memberikan saham dalam perdagangan merepresentasikan gotong royong diantara kerajaan Gowa dengan Portugis. Hubungan Gowa yang merupakan kerajaan Islam dan Portugis yang beragama Katolik merepresentasikan adanya sikap toleransi.

Analisis teks 8 Bab III Islamisasi dan Silang Budaya di Nusantara, sub bab Islam dan Jaringan Perdagangan Antar Pulau. Pada halaman 182 terdapat deskripsi.

Dalam
perdagangan telah terjalin
hubungan antaretnis yang
sangat erat. Berbagai etnis dari
kerajaan-kerajaan tersebut
kemudian berkumpul dan
membentuk komunitas. Oleh
karena itu, munculnama-nama
kampung berdasarkan asal
daerah. Misalnya,di Jakarta


terdapat perkampungan

Keling, Pekojan, dan kampung kampung lainnya yang berasal dari daerah-daerah asal yang jauh dari kota-kota yang dikunjungi, seperti Kampung Melayu, Kampung Bandan, Kampung Ambon, dan Kampung Bali.

Teks tersebut memberikan uraian tentang jaringan perdagangan pada masa Islam yang terbangun diantara kota-kota bandar besar yang beribu kota di pesisir seperti Banten, Jayakarta, Cirebon, JeparaDemak, Ternate Tidore, Gowa Tallo menimbulkan terjadinya akulturasi budaya. Sehingga terbentuk kampung India (Keling) dan Pekojan (Arab), Kampung Melayu, Kampung Bandan, Kampung Ambon, dan Kampung Bali di kota-kota pesisir seperti Jakarta.. Wacana pendidikan multikultural yang direpresentasikan oleh narasi teks tersebut adalah toleransi, kerukunan dan kebersamaan. Keberadaan berbagai macam perkampungan tidak menimbulkan gesekan diantara warga meskipun secara kultur budaya mereka berbeda. Mereka hidup secara harmonis dan damai.

Analisis teks 9 Bab III Islamisasi dan Silang Budaya di Nusantara, sub bab Proses Integrasi Nusantara. Pada halaman 250 terdapat deskripsi.

\begin{tabular}{lr}
\multicolumn{1}{r}{ Agama Islam yang } \\
masuk dan berkembang di \\
Nusantararangarkan \\
kebersamaan & mengajarkan \\
mengembangkan & toleransi \\
dalam kehidupan & beragama. \\
Islam mengajarkan persamaan \\
dan tidak mengenal kasta-kasta \\
dalam kehidupan masyarakat. \\
Konsep ajaran
\end{tabular}

memunculkan perilaku ke arah persatuan dan persamaan derajat.

Penulis buku ingin menyampaikan jika Islam sebagai agama perdamaian. Islam masuk ke Nusantara dengan tidak menyingkirkan kebudayaan lama dan agama yang telah berkembang seperti Hindu dan Budha. Islam berkembang secara berdampingan dengan agama Hindu dan Budha serta kebudayaan dan tradisi masyarakat Nusantara. Teks tersebut merepresentasikan wacana pendidikan multikultur dan pendidikan nilai. Wacana toleransi dapat dilihat dari narasi Islam mengajarkan kebersamaan yang mengarah terhadap sikap egaliter dan mengembangkan toleransi dalam kehidupan beragama. Wacana pendidikan nilai yang direpresentasikan teks tersebut adalah humanisme dimana Islam mengajarkan persamaan tidak mengenal stratifikasi sosial dalam masyarakat. Agama Islam memandang manusia secara sama yang membedakan hanya iman dan taqwanya. Sehingga tercipta persamaan derajad diantara semua manusia.

Analisis teks 10 Bab III Islamisasi dan Silang Budaya di Nusantara, sub bab Kesimpulan. Pada halaman 254 terdapat deskripsi.

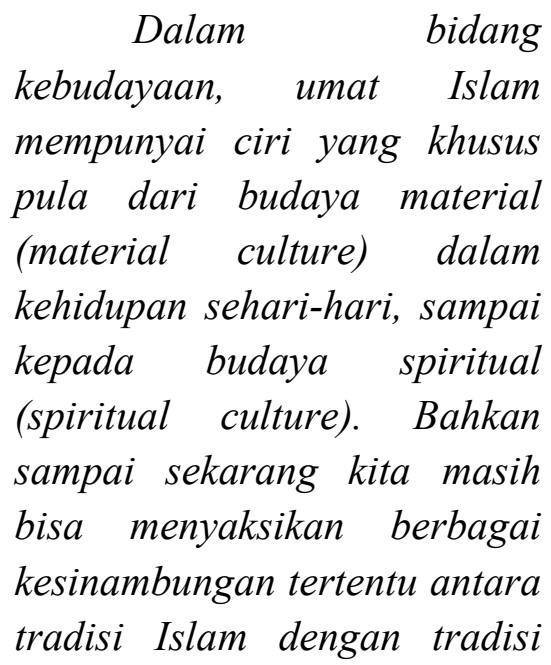


budaya spiritual pralslam yang sedikit banyak diwarnai tradisi Hindu, Buddha, dan bahkan tradisi keagamaan spritual lokal.

Narasi tersebut memberikan wacana pendidikan multikultural tentang nilai akomodatif dari agama Islam terhadap agama lain maupun tradisi-tradisi yang telah berkembang di Nusantara. Islam datang sebagai agama perdamaian. Islam tidak menyingkirkan agama terdahulu maupun tradisi yang telah ada. Islam justru hidup secara berdampingan dengan tradisi-tradisi yang telah ada di masyarakat. Tidak mengherankan jika muncul akulturasi (multikultural) kebudayaan antara Islam dengan tradisi lokal. Sebagai contoh budaya material seperti tradisi Sekaten yang diperingati di Surakarta dan Yogyakarta. Akulturasi bangunan Masjid Demak yang menggambarkan perpaduan arsutektur Hindu dan Islam.

Analisis teks 11 Bab III Islamisasi dan Silang Budaya di Nusantara, sub bab Kesimpulan. Pada halaman 255 terdapat deskripsi.

\section{Faktor pemersatu} terpenting di antara berbagai suku bangsa Nusantara adalah Islam. Islam mengatasi perbedaan-perbedaan yang terdapat di antara berbagai suku bangsa dan menjadi identitas yang mengatasi batasbatas geografis, sentimen etnis, identitas kesukuan, adat istiadat dan tradisi lokal lainnya. Tentu saja, sejauh menyangkut pemahaman dan pengamalan Islam, terdapat pula perbedaan-perbedaan tertentu terhadap doktrin dan

ajaran Islam sesuai rumusan para ulama, bukan dengan

identitas suku bangsa.

Teks tersebut merepresentasikan adanya wacana pendidikan multikultural dan pendidikan nilai berupa nilai humanisme. Islam merupakan agama bagi seluruh umat manusia dengan tidak membedakan ras, suku etnis dan kebudayaan manapun (toleransi). Peradaban Islam tumbuh dan berkembang untuk melawan segala bentuk diskriminasi dan ketidakadilan (Mahmudi, 2018:470). Umat Islam di Indonesia dari Sabang sampai Merauke berada dalam kesatuan dan bangunan Islam Nusantara. Islam di Nusantara mencoba bersifat terbuka dengan tradisi-tradisi lokal. Bentuk keterbukaan tersebut menciptakan akulturasi kebudayaan. Islam tidak berlawanan dengan kebudayaan yang telah ada tetapi mencoba melanjutkan kebudayaan yang telah ada. Walaupun tetap ada perbedaan dalam sisi menjalankan syariat dalam Islam. Sehingga akan tercipta tatanan masyarakat yang menjunjung tinggi nilai kerukunan (berbuat baik kepada sesama), gotong royong dan kebersamaan, musyawarah/demokratis, nilai pengendalian diri, nilai kasih sayang, adil dan bijaksana.

\section{Kesimpulan}

Pendidikan multikultural dan pendidikan nilai dalam pembelajaran sejarah menjadi sebuah keharusan diterapkan di sekolah-sekolah. Sajian materi tentang wacana pendidikan multikultural dan pendidikan nilai dalam buku teks sejarah cukup banyak ditemukan. Peranan guru menjadi penting untuk menghadirkan pembelajaran yang berorientasi kepada pembentukan karakter. Pada abad 21 dimana persebaran informasi yang cepat dan derasnya pengaruh globalisasi membuat berbagai macam budaya masuk ke Indonesia tanpa bisa 
dibendung. Budaya tersebut tidak semuanya sesuai dengan kepribadian bangsa Indobesia. Maka diperlukan pondasi karakter yang kuat untuk siswa agar tidak mudah terbawa arus negatif globalisasi. Melalui proses pembiasaan dan keteladanan yang diambil dari pembelajaran sejarah menjadikan siswa dapat mengambil nilai-nilai multikulturalisme dan pendidikan nilai yang mengalir dalam peristiwa sejarah untuk dijadikan pedoman dalam bertingkah laku dalam kehidupan sehari-hari baik di lingkungan keluarga, masyarakat, sekolah, negara bahkan internasional.

\section{Daftar Rujukan}

Fairclough, N. (2015). Critical Discourse Analysis. The Routledge Handbook of Applied Linguistics, February, 1-27. https://doi.org/10.4324/9780203835654

Gunawan, R., Lestariningsih, A. ., \& Sardiman. (2017). Buku Sejarah Indonesia Edisi Revisi. Kementerian Pendidikan dan Kebudayaan.
Haryatmoko. (2019). Critical Discourse Analysis. Rajawali Pers.

Kochar, S. (2008). Teaching of History. Grasindo.

Lickona, T. (2019). Educating for Character: Bagaimana Sekolah Dapat Memberikan Pendidikan tentang Sikap Hormat dan Bertanggung Jawab (U. \& S. Wahyudin (ed.); 1st ed.). Bumi Aksara.

Ozturgut, O. (2011). Understanding Multicultural Education. Current Issues in Education, 14 No. 2(August), 1-9.

Undang-Undang Nomor 20 Tentang Sistem Pendidikan Nasional, (2003).

Yuberti. (2014). Teori Pembelajaran dan Pengembangan Bahan Ajar Dalam Pendidikan. Anugrah Utama Raharja.

Zakiyah, D. ., \& Rudiana, A. (2014). Pendidikan Nilai Kajian dan Praktik di Sekolah. CV.Pustaka Setia. 